


\title{
THE EFFECT OF FERMENTED OIL PALM FRONDS IN DIET ON BODY WEIGHT GAIN AND MEAT QUALITY OF GOAT
}

\author{
E. Musnandar ${ }^{1}$, A.Hamidah ${ }^{2}$ and R.A. Muthalib ${ }^{1}$ \\ ${ }^{1}$ Faculty of Animal Science, Jambi University, Kampus Pinang Masak, \\ Jl.Raya Jambi-Muara Burlian Km 15 Mendalo Jambi 36361 - Indonesia \\ ${ }^{2}$ Faculty of Learning and Education, Jambi University, Kampus Pinang Masak, \\ Jl.Raya Jambi-Muara Burlian Km 15 Mendalo Jambi 36361 - Indonesia \\ Corresponding E-mail: endri.musnandar@yahoo.com
}

Received February 10, 2011; Accepted April 13, 2011

\begin{abstract}
The aims of study were to evaluate the use of fermented of oil palm fronds (FOPF) on body weight gain and meat quality of goat. This experiment was arranged in Completely Randomized Design with 3 treatments i.e. R1 (grass 0\%: FOPF 100\%), R2 (grass 50\%: FOPF 50\%) and R3 (grass 100\%: FOPF 0\%) and 5 replications. The parameters of the study were feed intake, average daily gain (ADG), weight and percentage of carcass and meat quality. The results indicated that feed intake and meat quality of goat was not affected by treatment, but the average daily gain, carcass weight, and percentage of carcass, was affected by the differences of percentage of FOPF in the pellet complete feed. The best ration was in the $\mathrm{R} 1$ ration (grass $0 \%$ : FOPF 100\%) that significantly different $(\mathrm{P}<0.05)$ from the other rations. The feed intake tended to be higher in goat fed R1 $(895.87 \mathrm{~g} / \mathrm{d})$ compared to those in goat with the R2 (854.38 $\mathrm{g} / \mathrm{d})$ and R3 (851.53 g/d). The average daily gain and carcass weight were higher in goat fed R1 ration compared to those in goat fed R2 and R3. Consequently, the carcass percentage in R1 was higher than those in R2 and R3. The carcass percentage was ranged from 38.41-41.38\%. The Ribeye area was higher in goat fed R1 $\left(9.73 \mathrm{~cm}^{2}\right)$ than R2 $\left(8.34 \mathrm{~cm}^{2}\right)$ and R3 $\left(7.76 \mathrm{~cm}^{2}\right)$. In this study, the protein content of goat meat was ranged from 19.06 to $20.71 \%$, lipid content was ranged from 0.703 to $1.106 \%$ and water content was range from $72.45 \%$ to $74.12 \%$, in which were not different among the treatments. It can be concluded that the use of FOPF in a complete feed could improve performance and meat quality of goat.

Keywords: carcass, goat, meat, oil palm frond
\end{abstract}

\section{INTRODUCTION}

Oil palm fronds (OPF) have high potency as feed that can replace the grass especially for the goat. According to Dinas Perkebunan of Jambi Province (2007), oil palm plantation area in Jambi Province reached 392,877 ha, with ages varying from 1 to 25 years, yields 6 tons of oil palm frond/ month/ha or reached 72 tons/year/ha. Palm tree that has been in production typically have 48 pieces of leaf oil palm with a 250-300 for each plant (Syarif, 2007).

The use of OPF for animal feed in a larger portion is still very limited due to the low quality (high content of crude fiber, low content of crude protein and low digestibility). Based on the nutritional content, OPF is suitable for ruminant feeds. The fiber of OPF content was high i.e. crude fiber (CF) $38.5 \%$, neutral detergent fiber (NDF) $78.7 \%$, acid detergent fiber (ADF) $55.6 \%$, while crude protein was low only $4.7 \%$ (Alimin and Bejo, 1995). In $1 \mathrm{~kg}$ DM OPF, there is $701 \mathrm{~g}$ NDF, 502 g ADF, $198 \mathrm{~g}$ hemicellulose, $424 \mathrm{~g}$ cellulose and $79 \mathrm{~g}$ acid detergent lignin (ADL), $111 \mathrm{~g} / \mathrm{kg}$ DM a soluble fraction, $207 \mathrm{~g} / \mathrm{kg}$ DM fraction of the potential for degradation in the rumen, degradation rate of $0.038 \mathrm{~g} / \mathrm{h}$ and the effective degradation of $213 \mathrm{~g} / \mathrm{kg}$ DM (Bengaly et $a l ., 2004)$. These values can be increased if the OPF was fermented, so it can be used as a feed ingredient in ruminant rations, especially goats. Various efforts to improve the quality of waste as a feed can be done through the physical treatment, chemical, biological or a combination of these treatments. One effort to improve the quality and digestibility of OPF is through the fermentation process which is intended to describe the bonding of cellulose and lignocellulose into an easily digestible feed substances. Degradation cellulolytic microorganisms in Biofad was 
determined by the level of activity of cellulase produced, the higher activity of cellulase, the higher the cellulose degradation process that will increase the availability of monosaccharides to the next process in the rumen. The addition of microorganisms in Biofad was expected to improve the quality of OPF through a fermentation process in terms of nutritional content as well as it's digestibility, so it can be used in a larger portion as feed in ruminant rations.

Previous authors (Zahari et al., 2003; Syarif, 2007; Mathius et al., 2004; Mathius, 2008; Hasan et al., 1992) conducted researches on OPF implementation for cow ration. There are no reports on goat especially on growth and meat quality. The objective of the study was to evaluate the effect of complete feed based fermented OPF (FOPF) with various proportions on body weight gain and meat quality of Ettawah Crossbred (EC) goat.

\section{MATERIALS AND METHODS}

This research was divided in 2 phases, namely the preliminary phase and data collection phase. The preliminary phase included the stage of preparing goats as research materials. Fifteen selected EC goats around 7-8 months old with the same relative weight was used. The research design used was completely randomized design (CRD) with 3 treatments namely R1 (Grass $0 \%$ :FOPF 100\%), R2 (Grass 50\%: FOPF 50\%), and R3 (Grass 100\% : FOPF 0\%) with 5 replications

Adaptation on farm and feed was done in two weeks, continuing observation and data collection in 12 weeks. In the preliminary phase of the research was carried out the randomizing of goat in farm, cutting hair and giving de-worming. The treatments were different the proportion of fermented OPF, those were $100 \%, 50 \%$ and $0 \%$ (Table 1). The ration was composed of $40 \%$ concentrate and $60 \%$ forages. Concentrates consisted of fish meal, molasses, and rice bran, while forage was field grass. The feeds were formulated in accordance to the goats' need based on the age and body weight. All of feed feedstuffs was grind, filtered with filter 60 mesh, and mixed and pelleted with a diameter of $6-8 \mathrm{~mm}$. There were 3 types of treatment diets. Fermented OPF (FOPF) is a product fermented by biofad and $4 \%$ urea for 14 days with DM 90.39\%, CF 35.26\%, $\mathrm{CP} 8.61 \%$, NDF $68.72 \%$, and $\mathrm{ADF} 52.96 \%$ (Musnandar et al., 2009)
In data collection phase, goats were fed twice a day, at 08.00 and 14.00, feed given and residual feed were weighed everyday, while drinking water provided ad libitum. Every 2 weeks body weights were weighed. The parameters observed in this study were:

1. Dry Matter intake $=$ (Feed givenresidual) $\mathrm{x} \% \mathrm{DM}$ of feed

2. $\mathrm{ADG}(\mathrm{g} / \mathrm{head} /$ day $)=[$ Final weight $(\mathrm{g})-$ initial weight $(\mathrm{g})] /$ (Day of measurement]

3. Carcass weight $(\mathrm{kg})$ was empty body weight minus weight of blood, head, feet, skin, and visceral except kidney, reproductive organ, and tail (Hasnudi et al., 2006).

Carcass yield $(\%)=[$ Carcass weight $/$ slaughter weight] x $100 \%$

Ribeye Area (muscle area) was measured after cutting between the $12^{\text {th }}$ and $13^{\text {th }}$ rib. The area was measured directly on the carcass with a grid (Boggs and Merkel, 1993).

Meat quality was determined by meat nutrient contents (water, fat, and protein) those were analyzed according to AOAC (2007). Data obtained were analyzed by analysis of variance. If there was significant effect of treatment then followed by Duncan's Multiple Range Test (Steel and Torrie, 1989).

\section{RESULTS AND DISCUSSION}

The average feed intake, average daily gain (ADG), carcass weight and yield, meat quality are presented in Table 2. The result showed that the feed consumption in three treatments were relatively similar. The result of analysis variance showed FOPF proportion were not significantly affecedt $(\mathrm{P}>0.05)$ on feed intake. This condition indicated that the FOPF can be consumed by goats without causing interference. Feed intake in this study was ranged from 851.53 to $895.87 \mathrm{~g} / \mathrm{d}$. The feed intake was difference to the results of Cameron et al. (2001) that feed consumption of goat with body weight $19.5 \mathrm{~kg}$ ranged from 751.77 to $758.75 \mathrm{~g} / \mathrm{d}$, a slight difference due to differences in the bred of goat (Boer Goat). This condition proved that the fermented of FOPF did not affect the number of rations consumed by the goat, thus giving FOPF in the ration does not affect to preference of goats.

The ADG of Ettawah Crossbred (EC) goat ranged from 65.36 to $120.7 \mathrm{~g} / \mathrm{d}$. The result of this study was better than Cameron et al. (2001) and 
Table 1. Composition and Nutrient Content of Dietary Experiment

\begin{tabular}{|c|c|c|c|}
\hline \multirow{2}{*}{ Feed } & \multicolumn{3}{|c|}{ Percentage of Oil Palm Fronds in Diet } \\
\hline & $100 \%$ FOPF & $50 \%$ FOPF & $0 \% \mathrm{FOPF}$ \\
\hline & & $. . \% \mathrm{DM} .$. & \\
\hline FOPF & 60 & 30 & 0 \\
\hline Field Grass & 0 & 30 & 60 \\
\hline Concentrate & 40 & 40 & 40 \\
\hline Fish Meal & 5 & 5 & 5 \\
\hline Molasses & 10 & 10 & 10 \\
\hline Rice Bran & 25 & 25 & 25 \\
\hline Total & 100 & 100 & 100 \\
\hline & & $\%$ & \\
\hline Crude Protein & 13.04 & 12.74 & 11.53 \\
\hline Crude Fiber & 20.39 & 20.25 & 20.09 \\
\hline NFE & 53.23 & 52.46 & 51.89 \\
\hline $\mathrm{EE}$ & 5.20 & 5.06 & 4.86 \\
\hline Ash & 8.14 & 9.49 & 11.63 \\
\hline Calcium & 0.70 & 0.65 & 0.56 \\
\hline Phosphor & 0.63 & 0.68 & 0.69 \\
\hline TDN & 68.87 & 67.86 & 67.93 \\
\hline
\end{tabular}

FOPF $=$ Fermented Oil Palm Fronds; NFE $=$ Nitrogen Free Extract EE $=$ Ether Extract TDN $=$ Total Digestible Nutrients.

Table 2. The Average Daily Gain, Body Weight, Percentage of Carcass and Quality of Goat Meat

\begin{tabular}{lccc}
\hline \multicolumn{1}{c}{ Parameter } & \multicolumn{3}{c}{ Treatment } \\
\cline { 2 - 4 } & $100 \%$ FOPF & $50 \%$ FOPF & $0 \%$ FOPF \\
\hline Dry matter Intake & 895.87 & 854.38 & 851.53 \\
Final body weight, kg & 18.50 & 18.07 & 16.68 \\
ADG, g/d & $120.71^{\mathrm{a}}$ & $106.79^{\mathrm{ab}}$ & $65.36^{\mathrm{b}}$ \\
Weight of Carcass, kg & $7.66^{\mathrm{a}}$ & $7.03^{\mathrm{ab}}$ & $6.41^{\mathrm{b}}$ \\
Carcass Yield, \% & $41.380^{\mathrm{a}}$ & $38.920^{\mathrm{ab}}$ & $38.410^{\mathrm{b}}$ \\
Ribeye Area, cm & $9.73^{\mathrm{a}}$ & $8.34^{\mathrm{ab}}$ & $7.76^{\mathrm{b}}$ \\
Meat Protein, \% & 20.712 & 19.602 & 20.622 \\
Meat Fat, \% & 1.106 & 1.022 & 0.703 \\
Meat Water, \% & 72.45 & 72.97 & 74.12 \\
\hline
\end{tabular}

Mean with different superscript at the same row indicates the significantly different $(\mathrm{P}<0.05)$

Limea et al. (2009), in which the ADG was 117 $\mathrm{g} / \mathrm{d}$ and $84.1 \mathrm{~g} / \mathrm{d}$, respectively. In this study, the highest ADG was $120.7 \mathrm{~g} / \mathrm{d}$, achieved by goat fed R1 (FOPF 100\%). This means that the fermentation process of FOPF not only could replace grass in the diet, but also increased weight gain of goat. This was due to goat fed R1 consumed higher than the other treatments. This condition also indicated that the ration of R1 had better ability to increase daily gain of goat than the other rations. This result also showed that the fermented of OPF has digestibility of organic matter that is quite good with low levels of crude fiber. Musnandar et al (2009) reported that 
fermentation could increase organic matter digestibility and decrease ADF level of OPF, each $50 \%$ and 5\%. Additionally, goat digested dry matter, organic matter, crude protein, crude fiber, and lignin of the diet more extent, it was attributable with longer retention time of ruminal fluid and particulate matters in the rumen and the entire gut, which then resulted in higher proportion of small size particles ( $<1 \mathrm{~mm}$ sieve) (Raharja et al., 2010)

Carcass weight and carcass yield (\%) were higher in R1 treatment (FOPF 100\%), suggested that administration of FOPF did not only replace grass but also gave a better growth performance. This condition is suspected because the higher crude protein had consumed in goat fed R1 than the others (Table 1). The average carcass yield obtained in this study was ranged from 38.41 to $41.38 \%$. The percentage of EC goat carcass in this study was higher than the percentage of Kacang goat carcass that was only 35\% (Musnandar, 2003), but lower than the percentage of Boer goat which was 46.4-48.8\% (Moore et al., 2002).

Table 2 showed that the treatments affected the value of Ribeye area. The value of Ribeye area in $\mathrm{R} 1$ treatment $\left(9.75 \mathrm{~cm}^{2}\right)$ was higher than $\mathrm{R} 2$ treatment $\left(8.34 \mathrm{~cm}^{2}\right)$ and $\mathrm{R} 3$ treatment $(7.76$ $\mathrm{cm}^{2}$ ) due to the carcass yield and final body weight in R1 treatment was higher than the other treatments. Lawrie (1990) state that Ribeye area was closely related to slaughter weight and carcass percentage. McLaughlin et al. (1994) reported that in Rambouillet sheep carcass with high percentage $(52.5 \%)$ produced $15.4 \mathrm{~cm}^{2}$ of ribeye area compared to the percentage of carcass $(51 \%)$ produced ribeye area of $15.1 \mathrm{~cm}^{2}$.

In this study, value of Ribeye area was ranged from $7.76-9.73 \mathrm{~cm}^{2}$. This value was higher than (Rudiono, 2000) that the value of Ribeye area was ranged from 2.504 to $6.44 \mathrm{~cm}^{2}$, this difference due to the bred of goat (Kacang goat) .

Results of other studies showed the Ribeye area on the lamb varied from 2.08 to $2.34 \mathrm{~cm}^{2}$ (Hufstedler et al., 1996). Wider variation was reported by Boggs and Merkel (1993) being from 2.5 to $10.25 \mathrm{~cm}^{2}$. The result of Brady et al. (2003) research showed that the ribeye area ranged from $11.61-25.60 \mathrm{~cm}^{2}$, this variation due to the difference of final body weight.

Table 2 showed that the treatments did not affect the protein content of meat, this situation because the protein content of meat is influenced by nutrition and animal activity (Lawrie, 1990). In this study, CP level in the treatments were differ, in which R1 contain the highest level of CP (Tabel 1), but the height level of CP in R1 treatment were not used to increase level of meat protein but to increase produce the meat (carcass), so that difference of CP in treatments unable to improve protein of meat. In addition, according to Lawrie (1990) nutritional deficiencies are not so important on the protein content, however, it could increase collagen content and decrease the percentage of flesh.

In this research, the goat looked after in individual cage during research so that the activities of goat were relatively similar, thereby goat activity unable to alter the meat protein content. The meat protein content was ranged from 19.06 to $20.71 \%$. Meat protein content was not different from the Lawrie (1990) that the meat protein content of adult mammal ranged from 19$22 \%$.

Meat fat content was ranged from 0.703 to $1.106 \%$ and was not different among the treatments. Fat content of meat goat is affected by nutrients (Lawrie, 1990). Tabel 1 showed that EE level and TDN level between the treatments were relatively similar so that contribution of EE to fat level of meat has same level. In addition to nutrition, age was also highly influenced on carcass fat. Age is a factor that can not be ignored in assessing carcass composition. However, due to goats in the present study had a similar age, so that meat fat content was similar among the treatments.

The water content in each treatment was not significantly different. This situation was due to moisture is strongly influenced by nutrition. High levels of nutrients can increase the fat content and lower water content. In nutrient-deficient animals, meat water content increased (Soeparno, 1998). In this research, the nutrient of the ration was relatively similar, thus water content of meat was not different. In this study, the water content of goat meat was ranged from 72.18 to $74.72 \%$, that was slightly different for sheep, amounting to $77 \%$ (Rachmawan, 2001). However, the water content of goat meat in this study was in the normal range, being around 75\% (Lawrie, 1990).

\section{CONCLUSION}

The fermented OPF can replace field grass in a complete feed. The use of FOPF tends to improve performance and meat quality of goat. 


\section{REFERENCES}

Alimin, A.R. dan M. H. Bejo. 1995. Feeding systems based on oil palm by-products in Malaysia. $1^{\text {st }}$ Int. Symp. On the integration of livestock to oil palm production. MASP/FAO and UPM, 25-27 th June 1995. Kuala Lumpur, Malaysia. Page 33 - 37.

A.O.A.C. 2007. Official Method of Analysis. Association of Official Analytical Chemist, Washington D.C.

Bengaly, K., J.B. Liang, Z.A. Jelan, Y.W. Ho and H.K. Ong. 2004. Optimalization of steam treatment as a method to increase in situ degradability of oil palm (Elaeis guineensis) fronds in Malaysia. Livestock Research for Rural Development : 16 (3):1-6.

Boggs, D.L. and R.A. Merkel. 1993. Live Animal Carcass Evaluation and Selection Manual. Fourth Edition. Kendall/Hunt Publishing Company, Iowa-USA.

Brady, A.S., K. E. Belk, S. B. LeValley, N. L. Dalsted, J. A. Scanga, J. D. Tatum and G. C. Smith. 2003. An evaluation of the lamb vision system as a predictor of lamb carcass red meat yield percentage. J.Anim.Sci. 81:1488-1498.

Cameron, M. R., J. Luo, T. Sahlu, S. P. Hart, S. W. Coleman and A. L. Goetsch. 2001. Growth and slaughter traits of Boer x Spanish, Boer $\mathrm{x}$ Angora, and Spanish goats consuming a concentrate-based diet . J.Anim.Sci. 79:1423-1430.

Dinas Perkebunan Provinsi Jambi. 2007. Statistik Perkebunan Provinsi Jambi Tahun 2007. Penerbit Badan Pusat Statistik Propinsi Jambi.

Hasnudi, Yunilas and F. Marbun. 2006. Pemanfaatan hasil sampingan perkebunan sebagai pakan tambahan bagi kambing kacang terhadap karkas serta perbandingan daging dan tulang selama penggemukan. Jurnal Agribisnis Peternakan, 2(2):1-5.

Hassan, A., O. M. Ishida, S. Oshio and T.J. Ahmad. 1992. Status of utilization fibrous crop residues and animal performance with emphasis on processing of oil palm fronds (OPF) for ruminant feed in Malaysia. Tropical Agriculture Research Center TARC No. 25. Ministry of Agriculture, Forestry and Fisheries, Tsukuba, Japan, Series 24: 135143.

Hufstedler, G.D., P.L. Gillma, G.E. Cartstens,
L.W. Greene, and N.D. Turner. 1996. Physiological and hormonal responses of lambs repeatedly implanted with zeranol and provide two levels of feed intake. J. Anim. Sci. 74:2376

Lawrie, R.A. 1990. Meat Science. $5^{\text {th }}$. Pergamon Press.

Liméa L., M. Boval, N. Mandonnet, G. Garcia, H. Archimède, and G. Alexandre. 2009. Growth performance, carcass quality, and noncarcass components of indigenous Caribbean goats under varying nutritional densities. J Anim Sci 87:3770-3781.

Mathius, I.W., Azmi, B.P. Manurung, D.M. Sitompul dan E. Priyatomo. 2004. Produk samping tanaman dan pengolahan kelapa sawit sebagai bahan pakan ternak sapi potong. Suatu Tinjauan. Prosiding Lokakarya Nasional. Sistem Integrasi Kelapa Sawit-Sapi. Bengkulu, 9-10 September 2003. Badan Penelitian dan Pengembangan Pertanian, bekerjasama dengan Pemerintah Provinsi Bengkulu dan PT. Agricinal. Page 120-128.

Mathius, I.W. 2008. Pengembangan sapi potong berbasis industri kelapa sawit. Pengembangan Inovasi Pertanian I (2): 206224.

McLaughlin, C. L., H. B. Hedrick, J. J. Veenhuizen, R. L. Hintz, L. Munyakazi, T. R. Kasser and C. A. Baile. 1994. Performance, clinical chemistry, and carcass responses of finishing lambs to formulated sometribove (methionyl bovine somatotropin). J Anim Sci. 72:2544-2551.

Moore, J. A., M. H. Poore and J.-M. Luginbuhl. 2002. By-product feeds for meat goats: Effects on digestibility, ruminal environment, and carcass characteristics. J. Anim. Sci. 80:1752-1758.

Musnandar, E. 2003. Reput Hayati Sabut Kelapa Sawit oleh Jamur Marasmius dan Implikasinya terhadap Performan Kambing. Disertasi Universitas Padjadjaran-Bandung.

Musnandar, E., A. Hamidah, and R.A. Muthalib. 2009. Efek fermentasi terhadap kualitas nutrisi dan kecernaan pelepah sawit. Jurnal Penelitian Universitas Jambi-Seri Sains 11(2):125-131.

Rachmawan, O. 2001. Bioteknologi Bungkil Biji Karet oleh Rhizopus oligosporus serta Implikasi Efeknya Terhadap Pertumbuhan dan Mutu Karkas/Daging Domba Priangan Jantan. Dissertation. Universitas 
Padjadjaran, Bandung.

Rahardja, D. P., V.S. Lestari and M. Hatta. 2010. Digestion of high fiber diet in sheep and goat of Jenepponto. J. Indonesian Trop. Anim. Agric. 35(3):151-157.

Rudiono, D. 2000. Pengaruh Dosis Hormon Testosteron Dan Umur Terhadap Performans Produksi Dan Residu Testosteron Pada Kambing Kacang Betina. Disertasi. Universitas Padjadjaran, Bandung.

Soeparno. 1998. Ilmu dan Teknologi Daging. $3^{\text {rd }}$ Edition. Gadjah Mada University Press, Yogyakarta.
Steel, R.G.D. and J.H. Torrie. 1989. Principle and Procedure Statistics. Second Edition. Mc Graw-Hill Book Co. Inc., Singapore.

Syarif, S. 2007. Uji palatabilitas beberapa bentuk olahan pelepah sawit terhadap ternak sapi. Jurnal Ilmiah Ilmu-ilmu Peternakan Agustus X (3):156-160.

Zahari, W. M., O.A. Hassan, H. K. Wong and J. B. Liang. 2003. Utilization oil palm frondbased diet for beef cattle production in Malaysia. Asian-Aust. J. Anim. Sci. 16 (4): 625-634. 